\title{
Antagonistic Potential of Dairy Origin Enterococcus faecium Against Multidrug-Resistant Foodborne Pathogens
}

\author{
SANA WAHEED ${ }^{1}$, MUHAMMAD HIDAYAT RASOOL ${ }^{1}$, BILAL ASLAM ${ }^{1}$, SAIMA \\ MUZAMMIL $^{1}$, MUHAMMAD WASEEM ${ }^{1}$, MUHAMMAD SHAHID ${ }^{2}$, MUHAMMAD \\ SAQIB $^{3}$, SUMREEN HAYAT ${ }^{1,4}$, MUHAMMAD NAEEM ${ }^{5}$, ZEESHAN TAJ ${ }^{1}$, SABA KABIR ${ }^{1,6,7}$, \\ MUHAMMAD SAQALEIN ${ }^{1}$, MUHAMMAD ATIF NISAR ${ }^{1}$, MOHSIN KHURSHID ${ }^{* 1}$
}

\author{
${ }^{1}$ Department of Microbiology, Government College University Faisalabad, Pakistan \\ ${ }^{2}$ Department of Bioinformatics and Biotechnology, Government College University Faisalabad, Pakistan \\ ${ }^{3}$ Department of Clinical Medicine and Surgery, University of Agriculture Faisalabad, Pakistan \\ ${ }^{4}$ Department of Biotechnology, University of Sargodha, Pakistan \\ ${ }^{5}$ College of Allied Health Professionals, Directorate of Medical Sciences, Government College University \\ Faisalabad, Pakistan \\ ${ }^{6}$ Department of Microbiology, Faculty of Life Sciences, University of Central Punjab, Lahore, Punjab, Pakistan \\ ${ }^{7}$ Department of Microbiology \& Molecular Genetics, University of the Punjab, Lahore, Punjab, Pakistan
}

\begin{abstract}
Probiotic potential of Enterococcus spp. is widely investigated around the globe. The biochemically and molecular characterized E. faecium strains isolated from Dahi (continental yogurt) were evaluated to tolerate simulated gastric environment, bile, sodium chloride, temperature, and $\mathrm{pH}$. The safety was assessed by disc diffusion, broth microdilution, antibiotic resistance genes screening, and hemolytic ability. Enterococci survived simulated gastrointestinal conditions and depicted growth at temperature $\left(15\right.$ to $\left.\geq 42^{\circ} \mathrm{C}\right), \mathrm{pH}(\leq 2.5$ to $\geq 9.5$ ), $0.3 \%$ bile salt and $3 \% \mathrm{NaCl}$. All strains were sensitive to ampicillin, vancomycin, kanamycin, gentamicin, streptomycin, tetracycline and ciprofloxacin and harbored vanR, vanX, qnrB2, qnrS, tet $\mathrm{K}$, and tet $\mathrm{W}$ resistance genes. E. faecium strains inhibited the E. coli $(85 \%)$ and S. Typhi $(50 \%)$ whereas the $10 \%$ cell-free culture supernatant (CFCS) of E. faecium halted the growth of E. coli while $15 \%$ CFCS completely suppressed S. Typhi. The cell-free culture supernatant retained antibacterial nature after $\mathrm{pH}$ and proteinase $\mathrm{K}$ treatment, however, it lost activity after heat treatment $\left(\geq 95^{\circ} \mathrm{C}\right)$. The genetic screening revealed that all isolates are capable to produce putrescine biogenic amine. Further assessment of strains for lack of infectivity, cytotoxicity in animals, adhesion to Caco-2 cells and characterization of enterocins is essential to conclude the probiotic potential of these strains.
\end{abstract}

Keywords Bacteriocins, Enteropathogens, Probiotics, Vancomycin susceptible enterococci.

To cite this article: WAHEED $S$, RASOOL MH, ASLAM B, MUZAMMIL S, WASEEM M, SHAHID M, SAQIB M, HAYAT S, NAEEM M, TAJ Z, KABIR S, SAQALEIN M, NISAR MA, KHURSHID M. Antagonistic Potential of Dairy Origin Enterococcus faecium Against Multidrug-Resistant Foodborne Pathogens. Rom Biotechnol Lett. 2021; 26(2): 2406-2415. DOI: 10.25083/rbl/26.2/2406.2415 


\section{Introduction}

Bifidobacterium, Enterococcus, and Lactobacillus are important bacterial probiotic genera. These microbes have diverse functional attributes including competitive intestinal colonization, maintenance of mucosal integrity, immunomodulation, biosynthesis of digestive enzyme, the bioavailability of micronutrients and trace metals, bioactive proteins and organic acids biosynthesis (KHURSHID et al, 2015, KHAN et al, 2013).

Enterococci are ubiquitous lactic acid bacilli (LAB), present in different ecological niches and harbors both probiotic and pathogenic traits. Enterococcus faecium is a LAB that belongs to phylum Firmicutes (low G+C) with a genome size of approximately 2.6Mb (AZIZ et al, 2019). Members of E. faecium are acid and salt tolerant and exist in various traditional fermented foods of animal and plant origin and found in the gut of animals as well. These microbes are adapted to survive harsh acidic conditions and bile salts in the gastrointestinal tract. Probiotic traits like competitive adhesion to gut epithelium, antagonistic behavior to enteropathogens, production of antibacterial peptides, stimulation of immunomodulatory response and stabilization of gut microenvironment are key features of E. faecium (HANCHI et al, 2018, SHAHID et al, 2017). However, to date, no single enterococci got status of GRAS (generally recognized as safe) from EFSA (European Food Safety Authority), but few probiotic strains are being used as additives in animal feed to overcome diarrhea and as growth promoters (LAULUND et al, 2017, FRANZ et al, 2011).

It is generally understood that the bacterial species used as probiotics may also acquire the antibiotic resistance genes due to their shared environment in the human or animal digestive tract (GUEIMONDE et al, 2013). The emergence of multi-antibiotic resistance and nosocomial infections are two major hurdles in GRAS legislative reforms (DUBIN and PAMER, 2014). Enterococci possess resistance against multiple classes of antibiotics including penicillin, cephalosporins, aminoglycosides, glycopeptides, macrolides, tetracyclines and quinolones (MILLER et al, 2014). There are multiple reports representing the transfer of resistance genes from enterococci to other Gram-positive bacteria. Substantial evidence is available in literature citing the involvement of enterococci in various infections including endocarditis, nosocomial bacteremia, and urinary tract infections (WEINER et al, 2016). For the safety assessment of Enterococci, the susceptibility to glycopeptide i.e. vancomycin susceptibility is a major criterion. It is quite fortunate, that the genes encoding vancomycin resistance; vanA and vanB are rarely found among the enterococci strains from the food sources. Moreover, another criterion for the safety assessment of the Enterococci intended to be used in the food products is the absence of transferable antibiotic-resistant genes (ZOMMITI et al, 2018).
There is huge diversity in the human intestinal microbiome based on geographical habitats, human races, age groupings, communities with unique dietary traditions and other niches such as old-style fermented food products. The relevant scientific information is lacking from Pakistan and no such database is available yet (ZHAO et al, 2019). This needs wide-ranging collaborative studies from various scientific groups in the country to develop the National Microbiome databank from diverse populations. Moreover, no native probiotic strain is available commercially in Pakistan and the market is having probiotic preparations of foreign origin. Hence, the exploration of local probiotic strains with specific health benefits and safety concerns is scientifically validated and clinically proven in the local settings is required. Therefore, this study is a continuation of ongoing research work for the evaluation of the antibacterial activity of different putative probiotic strains isolated locally against common enteropathogens as well as to appreciate the probiotic potential of E. faecium strains.

\section{Materials and Methods}

\section{Bacterial Isolates and Culture Conditions}

A total of four different Enterococcus faecium strains were isolated from continental yogurt (Dahi) from the street vended Dahi purchased from various markets of Faisalabad, Pakistan. The Dahi samples were cultured on MRS (deMan-Rogosa-Sharpe, pH 6.5 Himedia ${ }^{\mathrm{TM}}$, India) medium supplemented with $0.05 \%$ L-cysteine under microaerophilic conditions at $37^{\circ} \mathrm{C}$ for 24 to 36 hours (NAMI et al, 2019).

The enteropathogenic bacteria were obtained from the clinical specimens obtained from hospitalized patients and were characterized using phenotypic and molecular methods. These include Salmonella enterica subsp. enterica serovar Typhi SABA10 (Accession No. KY305432) and Escherichia coli SABA3 (Accession No. KY305421) which were cultured on MacConkey agar (Oxoid $\left.{ }^{\mathrm{TM}}, \mathrm{UK}\right)$ and LB broth $\left(\mathrm{Oxoid}^{\mathrm{TM}}\right.$, UK) under aerobic conditions at $37^{\circ} \mathrm{C}$ for 18 hours before the experiments. The drug susceptibility to various antimicrobial agents was performed using VITEK® 2 (bioMérieux, Marcy l'Étoile, France) and interpreted as per CLSI guidelines (CLSI, 2018) and classified as multidrug-resistant (MDR) according to the criteria described previously (MAGIORAKOS et al, 2012).

\section{Biochemical and Molecular Characterization of Enterococci}

Different biochemical tests including $\mathrm{H}_{2} \mathrm{~S}$ production, Voges-Proskauer, citrate utilization, catalase, oxidase, esculin hydrolysis, pyrrolidinyl peptidase, CAMP, and Dnase production were performed for identification and differentiation from streptococci. To decipher metabolic diversity, different monosaccharides (adonitol, arabinose, ribose, dulcitol, galactose, glucose, mannitol, mannose, and sorbitol) and disaccharides (lactose, maltose, and sucrose) 
were used for substrate fermentation (Manero and Blanch, 1999). Finally, isolates were characterized by sequence analysis of the 16S rRNA gene. Briefly, the genomic DNA of isolates was extracted using GF-1 Bacterial DNA Extraction Kit (Vivantis Technologies Sdn. Bhd., Malaysia) and the 16S rRNA gene was amplified using universal primers (27F: AGAGTTTGATCMTGGCTCAG and 1492R: TACGGYTACCTTGTTACGACTT). The amplicons were purified by QIAquick PCR Purification Kit (Qiagen $\mathrm{GmbH}$, Germany) and sequenced from Macrogen ${ }^{\mathrm{TM}}$, Seoul, Korea. Sequence alignment and analysis was done using MEGA 7.0 (Mega software), ChromasPro (Technelysium Pty Ltd.) and NCBI BLAST tool, the aligned sequences were submitted to GenBank for allocation accession numbers.

\section{Evaluation of Probiotic Potential}

The probiotic potential of enterococci was assessed by different physiochemical tests simulating gastrointestinal tract (GIT) conditions of mammals.

Acid-Base Tolerance: Ability of enterococci to endure harsh acidic conditions of the stomach and basic milieu of the small intestine was determined by cultivating in MRS broth of different $\mathrm{pH}$ ranging from 1.5 to 9.0. The cell biomass $(\mathrm{mg})$ was estimated as a function of bacterial growth.

Bile Salt and Sodium Chloride Tolerance: Bile salt resistance was checked by cultivation on MRS agar containing $0.3 \%(\mathrm{w} / \mathrm{v})$ of sodium deoxycholate (SigmaAldrich $^{\mathrm{TM}}$, USA). However, to evaluate $\mathrm{NaCl}$ tolerance, the isolates were cultured in MRS broth containing $\mathrm{NaCl}$ (0.1 to $3.0 \% \mathrm{w} / \mathrm{v}$, Sigma-Aldrich ${ }^{\mathrm{TM}}$, USA) and cell dry weight (mg) was recorded as a function of bacterial growth.

Temperature Tolerance: Enterococci were cultured in broth medium and incubated at different temperatures (15 to $42^{\circ} \mathrm{C}$ ), cellular biomass was measured as growth function. Lastly, the growth curves of all isolates were plotted by measuring optical density at $630 \mathrm{~nm}$ wavelength using UV-VIS Double Beam Spectrophotometer- UV-1900 (Shimadzu Scientific Instruments Inc. USA) as bacterial growth function.

Safety Assessment of Enterococci: Hemolytic activity and antibiotic susceptibility profiling were chosen to delineate the safety of enterococci.

Hemolytic Activity: The isolates were cultured on $5 \%$ defibrinized sheep blood containing Columbia Blood agar $\left(\right.$ Oxoid $\left.^{\mathrm{TM}}, \mathrm{UK}\right)$ under microaerophilic conditions at $37^{\circ} \mathrm{C}$ for 48 hours (TOĞAY et al, 2010).

Antibiotic Susceptibility Profiling: Antibiotic sensitivity testing was performed by Kirby-Bauer disc diffusion method and minimum inhibitory concentration (MIC $\mu \mathrm{g} / \mathrm{ml}$ ) was determined by broth micro-dilution assay.

Kirby-Bauer Disc Diffusion Assay: Total 07 different types of antibiotic discs (Oxoid ${ }^{\mathrm{TM}}$, UK) namely ampicillin $(10 \mu \mathrm{g})$, vancomycin $(30 \mu \mathrm{g})$, kanamycin $(30 \mu \mathrm{g})$, gentamicin $(10 \mu \mathrm{g})$, streptomycin $(25 \mu \mathrm{g})$, tetracycline
$(30 \mu \mathrm{g})$ and ciprofloxacin $(5 \mu \mathrm{g})$, recommended by EFSA (European Food Safety Authority) and CLSI (Clinical \& Laboratory Standards Institute) were selected for antibiotic sensitivity testing (RYCHEN et al, 2018, CLSI, 2018).

\section{Determination of Minimum Inhibitory Concen- tration}

MIC $(\mu \mathrm{g} / \mathrm{ml})$ of isolates against ampicillin, vancomycin, kanamycin, gentamicin, streptomycin, tetracycline and ciprofloxacin (Sigma-Aldrich ${ }^{\mathrm{TM}}$, USA) was determined by broth micro-dilution assay. Initially, successive dilutions of antibiotics were made in Mueller Hinton broth $\left(\mathrm{Oxoid}^{\mathrm{TM}}, \mathrm{UK}\right)$ and then $0.5 \mathrm{McF}$ arland standard of isolates were inoculated in $U$ shaped 96 well plates followed by incubation $37^{\circ} \mathrm{C}$ for $16-20$ hours. Absorbance $(\lambda=630 \mathrm{~nm})$ was measured using Multiskan ${ }^{\mathrm{TM}}$ FC Microplate Photometer (Thermo Fisher Scientific ${ }^{\mathrm{TM}}$, USA) and results were interpreted as per guidelines of EFSA and CLSI (RYCHEN et al, 2018, CLSI, 2018).

\section{Molecular Detection of Antibiotic Resistance Determinants}

Isolated enterococci were subjected to PCR amplification for the screening of antimicrobial resistance markers. Different primers were selected for screening of $\beta$-lactam (blaZ) vancomycin (van $\mathrm{R}$ and van $\mathrm{X}$ ), quinolones $(q n r \mathrm{~A}, q n r \mathrm{~B} 1, q n r \mathrm{~B} 2$ and $q n r \mathrm{~S})$, tetracycline (tet $\mathrm{K}$ and tet $\mathrm{W}$ ) and macrolide (mef A and mef $\mathrm{E}$ ) resistance genes (CHANG et al, 2009, AARESTRUP et al, 2000).

\section{Assessment of Antagonistic Activity against Enteropathogens}

Antibacterial activity of enterococci isolates and their cell-free culture supernatant (CFCS) was determined against antimicrobial-resistant enteropathogens: Salmonella enterica subsp. enterica serovar Typhi SABA10 (Accession No. KY305432) and Escherichia coli SABA3 (Accession No. KY305421). Four different methods viz., cross streak line, co-culture, agar well diffusion, and micro broth growth inhibition assays were selected for the determination of antagonistic potential (TODOROV AND DICKS, 2004).

Cross Streak Line Method: Enterococci were cultured on nutrient and tryptic soy agar, culture plates were inactivated by two-hour treatment with gaseous chloroform, followed by culturing of pathogenic bacteria. The zone of inhibition around the enterococci was measured for the determination of antibacterial activity.

Enterococci and Enteropathogen Co-Culture Assay: Cell suspension of $0.5 \mathrm{McFarland}$ standards of enterococci and enteric pathogens were co-cultured in brain-heart infusion (BHI) broth. Monoculture of pathogens cultivated in BHI broth was taken as control. Then, both monoculture and co-cultures were serially diluted and cultured on MacConkey agar and \% inhibition was calculated by using the following mathematical formula: 
$\%$ Inhibition $=($ Control $\mathrm{CFU} / \mathrm{ml}-\mathrm{Co}$-culture $\mathrm{CFU} / \mathrm{ml} \times 100) /$ (Control $\mathrm{CFU} / \mathrm{ml})$

Agar Well Diffusion Assay: Cell suspension of the enteric pathogen (0.5 McFarland standard) was cultured on BHI agar then wells (diameter $=6 \mathrm{~mm}$ ) were prepared in the agar. The test wells were inoculated with filtersterilized enterococci CFCS whereas control well was inoculated with sterile MRS broth. The zone of inhibition $(\mathrm{mm})$ was measured to estimate antimicrobial activity.

Micro broth Growth Inhibition Assay: Enteropathogens E. coli and S. Typhi cultured in nutrient and BHI broth respectively were mixed in different dilutions of CFCS (5\%, 10\% and 15\% v/v) and incubated for 8 hours. Absorbance $(\lambda=630 \mathrm{~nm})$ was measured at regular intervals as a function of bacterial growth.

Characterization of CFCS: CFCS was subjected to thin-layer chromatography (TLC) for organic acid profiling. Silica coated TLC plate was used as a stationary phase, whereas mixture water, chloroform, ethanol, ammonium hydroxide and acetone (2:6:10:22:60) were used as mobile phase (LEE et al, 2001). 10\% (w/v) solutions of different organic acid namely propionic, lactic, formic, citric, butyric, ascorbic and acetic acid were used as standards. Then the effect of temperature $\left(25\right.$ to $\left.60^{\circ} \mathrm{C}\right), \mathrm{pH}$ (3.0 to 9.0) and proteinase K on CFCS was determined.

Molecular Detection of Biogenic Amines: Using specific primers genomic DNA of isolates was subjected for detection of histidine decarboxylase ( $h d c$ histamine producing gene) and ornithine decarboxylase (odc putrescine synthesizing gene) (TURPIN et al, 2011).

\section{Results}

\section{Identification of Enterococci}

Four different enterococci were isolated from continental yogurt (Dahi) and named as L1, L2, L7, and L8. L1 and L7 displayed the highest levels of homology with E. faecium (Accession No. CP035136, isolated from Korea), L2 with Enterococcus sp. (Accession No. KP256009, isolation source Pakistani Dahi), whereas L8 depicted the highest identity with E. faecium (Accession No. AP019394, eutrophic Egyptian soil). The isolates L1, L2, L7, and L8 were submitted to GenBank as follows: E. faecium SANA1 (Accession No. KX609793), E. faecium SANA2 (Accession No. KX609794), E. faecium SANA7 (Accession No. KX609795) and E. faecium SANA8 (Accession No. KX609796), respectively (Fig. 1). The isolates were found catalase, urease, ornithine decarboxylase, phenylalanine deaminase, lysine decarboxylase, and oxidase negative, however, they displayed the presence of arginine dihydrolase, $\beta$-galactosidase, leucine arylamidase, and pyrrolidonyl aminopeptidase. Importantly, all isolates were metabolically diverse and can ferment different monosaccharides (5C and 6C) and disaccharides. In contrast to other enterococci, E. faecium SANA1 was found particularly diverse as it fermented all of the tested sugars (Table 1).
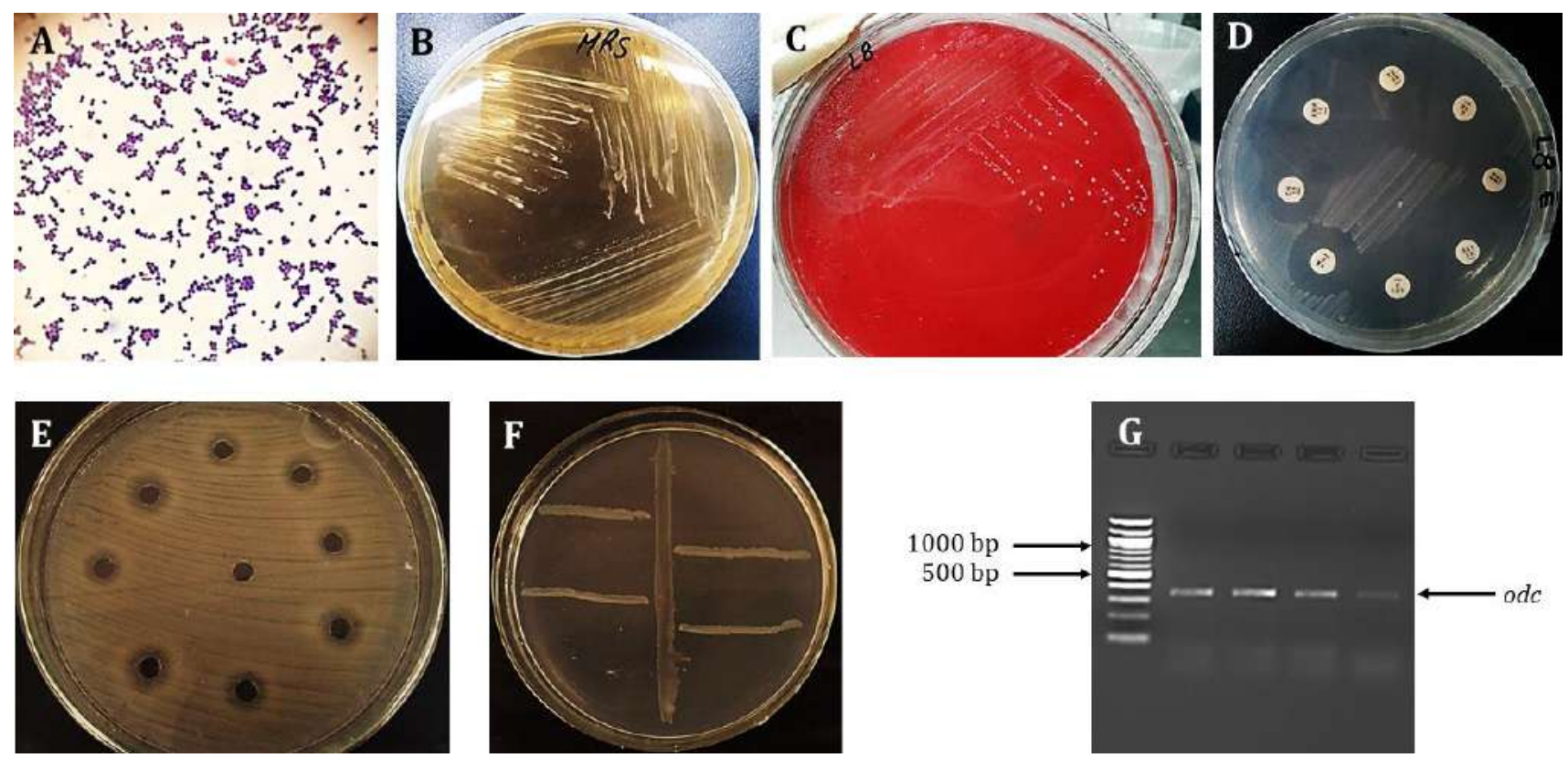

Figure 1. Phenotypic and genetic characterization of enterococci. A: Gram staining, B: culturing on MRS agar, C: non-hemolytic behavior observed on blood agar, D: antibiotic susceptibility assay, E: assessment of antagonistic activity by agar well assay, F: determination of antibacterial activity by cross-streak line method, G: amplification of odc (putrescine biosynthesis) gene. 
Table 1. Biochemical profile of E. faecium isolates

\begin{tabular}{|c|c|c|c|c|}
\hline & E. faecium SANA1 & E. faecium SANA2 & E. faecium SANA7 & E. faecium SANA8 \\
\hline \multicolumn{5}{|c|}{ Microscopic Examination } \\
\hline Gram reaction & Gram +ve & Gram +ve & Gram +ve & Gram +ve \\
\hline Cell shape & Cocci & Cocci & Cocci & Cocci \\
\hline Spore staining & - & - & - & - \\
\hline \multicolumn{5}{|c|}{ Carbohydrate Metabolism } \\
\hline Adonitol (5C) & + & - & + & - \\
\hline Arabinose (5C) & + & + & - & - \\
\hline Ribose (5C) & + & + & + & + \\
\hline Dulcitol (6C) & + & - & - & - \\
\hline Galactose (6C) & + & + & + & + \\
\hline Glucose (6C) & + & + & + & + \\
\hline Mannitol (6C) & + & + & + & + \\
\hline Mannose (6C) & + & + & + & + \\
\hline Sorbitol (6C) & + & + & - & + \\
\hline Lactose (disaccharide) & + & + & + & + \\
\hline Maltose (disaccharide) & + & + & + & + \\
\hline Sucrose (disaccharide) & + & + & + & + \\
\hline \multicolumn{5}{|c|}{ Biochemical Tests } \\
\hline Gas production & + & + & + & + \\
\hline $\mathrm{H}_{2} \mathrm{~S}$ production & - & - & - & - \\
\hline Voges-Proskauer & + & + & + & + \\
\hline Methyl Red & + & + & + & + \\
\hline Citrate & - & - & - & - \\
\hline Catalase & - & - & - & - \\
\hline Oxidase & - & - & - & - \\
\hline Indole & - & - & - & - \\
\hline Urease & - & - & - & - \\
\hline Esculin hydrolysis & + & + & + & + \\
\hline Pyrrolidonyl peptidase & - & - & - & - \\
\hline CAMP & - & - & - & - \\
\hline$\alpha$-hemolysis & - & - & - & - \\
\hline$\beta$-hemolysis & - & - & - & - \\
\hline$\gamma$-hemolysis & + & + & + & + \\
\hline Dnase & - & - & - & - \\
\hline \multicolumn{5}{|c|}{ Growth Conditions } \\
\hline pH optima & 5.5 & 5.5 & 5.5 & 5.5 \\
\hline Temperature optima & $37^{\circ} \mathrm{C}$ & $37^{\circ} \mathrm{C}$ & $37^{\circ} \mathrm{C}$ & $\geq 37^{\circ} \mathrm{C}$ \\
\hline \multicolumn{5}{|c|}{ Secreted Acids } \\
\hline Lactic acid & + & + & + & + \\
\hline Acetic acid & + & + & + & + \\
\hline
\end{tabular}

\section{Assessment of Probiotic Potential and Biosafety}

GIT simulation studies were conducted to delineate the probiotic potential of isolates. All enterococci survived acidic ( $\leq 2.5$ to 6.5 ) and basic $\mathrm{pH}(7.5$ to $\geq 9.5$ ), whereas optimum growth was observed as $\mathrm{pH}$ 5.5. Moreover, all isolates tolerated bile salt and osmotic stress of $3 \% \mathrm{NaCl}$. All enterococci grew and tolerated a wide range of temperatures $\left(15\right.$ to $\geq 42^{\circ} \mathrm{C}$ ) with temperature optima $37^{\circ} \mathrm{C}$ (Fig. 2). The isolates were non-hemolytic in nature and depicted $\gamma$-hemolysis on blood agar plates (Fig. $1 \mathrm{C}$ ). According to disc diffusion assay, all isolates were sensitive to ampicillin, gentamicin, amikacin, tetracycline, doxycycline, levofloxacin, ciprofloxacin, sulfamethoxazole- trimethoprim and vancomycin (Fig. 1 D, Table 2). Moreover, broth microdilution assays delineated that all isolates were susceptible to ampicillin (MIC $0.5 \mu \mathrm{g} / \mathrm{ml}$ ), vancomycin (MIC 0.5-1 $\mu \mathrm{g} / \mathrm{ml}$ ), kanamycin (MIC 128$512 \mu \mathrm{g} / \mathrm{ml}$ ), gentamicin (MIC 8-16 $\mu \mathrm{g} / \mathrm{ml}$ ), streptomycin (MIC 32-64 $\mu \mathrm{g} / \mathrm{ml}$ ), tetracycline (MIC 1-2 $\mu \mathrm{g} / \mathrm{ml}$ ) and ciprofloxacin (MIC 1-2 $\mu \mathrm{g} / \mathrm{ml}$ ) (Table 3 ). The genetic screening revealed that none of the isolates contained blaZ, $m e f \mathrm{~A}$ and $m e f \mathrm{E}$ antibiotic resistance genes. However, all enterococci harbored $q n r \mathrm{~S}$, tet $\mathrm{K}$, and tet $\mathrm{W}$ resistance determinants. Moreover, except E. faecium SANA8 all isolates harbored $v a n \mathrm{R}, \operatorname{vanX}$, and $q n r \mathrm{~B} 2$ resistance genes as well (Table 2). 


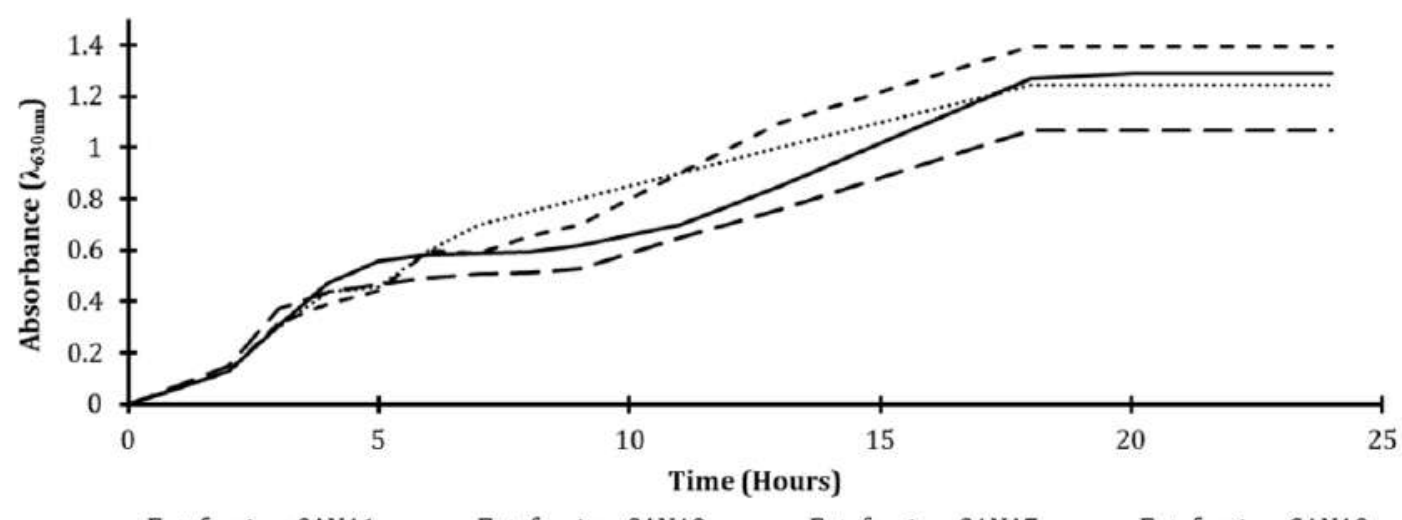

—Ent.faecium SANA1 - - Ent.faecium SANA2 - - Ent.faecium SANA7 …..... Ent.faecium SANA8

Figure 2. Growth patterns of enterococci under aerobic conditions at $37^{\circ} \mathrm{C}$

Table 2. Antimicrobial susceptibility and antimicrobial resistance determinants of LABs

\begin{tabular}{|c|c|c|}
\hline Isolates & Phenotypes & Genotypes \\
\hline E. faecium SANA1 & $\mathrm{Amp}^{\mathrm{S}}, \mathrm{Gen}^{\mathrm{S}}, \mathrm{Ak}^{\mathrm{S}}, \mathrm{Tet}^{\mathrm{S}}, \mathrm{Do}^{\mathrm{S}}, \mathrm{Lev}^{\mathrm{S}}, \mathrm{C}^{\mathrm{S}}, \mathrm{Sxt}^{\mathrm{S}}, \mathrm{Van}^{\mathrm{S}}$ & van $\mathrm{R}, \operatorname{vanX}$, qnr $\mathrm{B} 2$, qnr $\mathrm{S}$, tet $\mathrm{K}$, tet $\mathrm{W}$ \\
\hline E. faecium SANA2 & $\mathrm{Amp}^{\mathrm{S}}, \mathrm{Gen}^{\mathrm{S}}, \mathrm{Ak}^{\mathrm{S}}, \mathrm{Tet}^{\mathrm{S}}, \mathrm{Do}^{\mathrm{S}}, \mathrm{Lev}^{\mathrm{S}}, \mathrm{C}^{\mathrm{S}}, \mathrm{Sxt}^{\mathrm{S}}, \mathrm{Van}^{\mathrm{S}}$ & vanX, qnr $\mathrm{A}, q n r \mathrm{~B} 2, q n r \mathrm{~S}$, tet $\mathrm{K}$, tet $\mathrm{W}$ \\
\hline E. faecium SANA7 & $\mathrm{Amp}^{\mathrm{S}}, \mathrm{Gen}^{\mathrm{S}}, \mathrm{Ak}^{\mathrm{S}}, \mathrm{Tet}^{\mathrm{S}}, \mathrm{Do}^{\mathrm{S}}, \mathrm{Lev}^{\mathrm{S}}, \mathrm{C}^{\mathrm{S}}, \mathrm{Sxt}^{\mathrm{S}}, \mathrm{Van}^{\mathrm{S}}$ & van $\mathrm{R}, \operatorname{vanX}, q n r \mathrm{~A}, q n r \mathrm{~B} 2, q n r \mathrm{~S}$, tet $\mathrm{K}$, tet $\mathrm{W}$ \\
\hline E. faecium SANA8 & $\mathrm{Amp}^{\mathrm{S}}, \mathrm{Gen}^{\mathrm{S}}, \mathrm{Ak}^{\mathrm{S}}, \mathrm{Tet}^{\mathrm{S}}, \mathrm{Do}^{\mathrm{S}}, \mathrm{Lev}^{\mathrm{S}}, \mathrm{C}^{\mathrm{S}}, \mathrm{Sxt}^{\mathrm{S}}, \mathrm{Van}^{\mathrm{S}}$ & $q n r \mathrm{~S}$, tet $\mathrm{K}$, tet $\mathrm{W}$ \\
\hline
\end{tabular}

Amp: ampicillin, Gen: gentamicin, Ak: amikacin, Tet: tetracycline, Do: doxycycline, Lev: levofloxacin, C: ciprofloxacin, Sxt: sulfamethoxazole-trimethoprim and Van: vancomycin

Table 3. MIC $(\mu \mathrm{g} / \mathrm{ml})$ of selected antibiotics for E. faecium isolates

\begin{tabular}{llccccc}
\hline Antimicrobial Class & Antibiotics & $\begin{array}{c}\text { EFSA Cut-off } \\
\text { Values }(\boldsymbol{\mu g} / \mathbf{m l})\end{array}$ & $\begin{array}{c}\text { E. faecium } \\
\text { SANA1 }\end{array}$ & $\begin{array}{c}\text { E. faecium } \\
\text { SANA2 }\end{array}$ & $\begin{array}{c}\text { E. faecium } \\
\text { SANA7 }\end{array}$ & $\begin{array}{c}\text { E. faecium } \\
\text { SANA8 }\end{array}$ \\
\hline Penicillins & Ampicillin & 2 & $0.5(\mathrm{~S})$ & $0.5(\mathrm{~S})$ & $1(\mathrm{~S})$ & $1(\mathrm{~S})$ \\
\hline Glycopeptides & Vancomycin & 4 & $0.5(\mathrm{~S})$ & $0.5(\mathrm{~S})$ & $1(\mathrm{~S})$ & $1(\mathrm{~S})$ \\
\hline Aminoglycosides & Kanamycin & 1024 & $128(\mathrm{~S})$ & $512(\mathrm{~S})$ & $256(\mathrm{~S})$ & $512(\mathrm{~S})$ \\
\cline { 2 - 7 } & Gentamicin & 32 & $8(\mathrm{~S})$ & $16(\mathrm{~S})$ & $16(\mathrm{~S})$ & $16(\mathrm{~S})$ \\
\cline { 2 - 7 } & Streptomycin & 128 & $32(\mathrm{~S})$ & $64(\mathrm{~S})$ & $64(\mathrm{~S})$ & $32(\mathrm{~S})$ \\
\hline Tetracyclines & Tetracycline & 4 & $1(\mathrm{~S})$ & $2(\mathrm{~S})$ & $2(\mathrm{~S})$ & $2(\mathrm{~S})$ \\
\hline Quinolones & Ciprofloxacin & $\geq 4^{*}$ & $1(\mathrm{~S})$ & $1(\mathrm{~S})$ & $2(\mathrm{~S})$ & $2(\mathrm{~S})$ \\
\hline
\end{tabular}

The EFSA cut-off values were used as standards for assigning the status of sensitive (S) and resistant (R)

*Ciprofloxacin MIC values were taken from CLSI 2018 for Enterococcus sp.

\section{Antimicrobial Activity of Enterococci against Enteropathogens}

In vitro, antagonistic activity of enterococci was measured against enteropathogenic E. coli SABA3 and S. Typhi SABA10 (Fig. $1 \mathrm{E}$ and $1 \mathrm{~F}$ ). All enterococci and their CFCS displayed significant antibacterial activity against test pathogens. According to E. faecium SANA1 depicted strong antagonistic activity and reduced growth of E. coli SABA3 (approximately 85\%) and S. Typhi SABA10 (approximately 50\%). Moreover, $10 \%$ CFCS of E. faecium SANA1 was enough to inhibit the growth of $E$. coli SABA3 and the growth of S. Typhi SABA10 was drastically reduced by $15 \%$ CFCS (Fig. 3). 

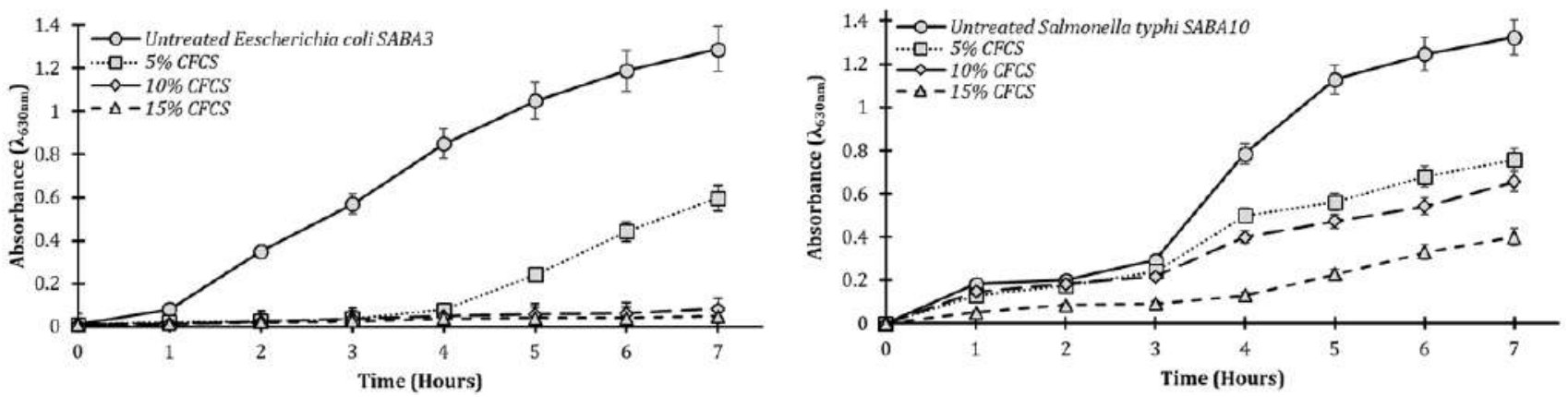

Figure 3. Antibacterial activity of E. faecium SANA1 CFCS against E. coli and S. Typhi

\section{Physiochemical Nature of CFCS}

TLC analysis of CFCS of all enterococci revealed the presence of two non-volatile organic acids namely lactic and acetic acid. Furthermore, the antagonistic activity of CFCS remained unaltered after $\mathrm{pH}$ and proteinase $\mathrm{K}$ treatment. However, CFCS lost its activity after heat treatment $\left(\geq 95^{\circ} \mathrm{C}\right)$. According to our examination, enterococci CFCS harbors organic acids and antimicrobial peptides.

\section{Screening of Biogenic Amine Genes}

According to PCR results, all isolates harbored putrescine synthesizing gene odc (ornithine decarboxylase), whereas histamine producing gene $h d c$ (histidine decarboxylase) was absent in all isolates (Fig. $1 \mathrm{G}$ ).

\section{Discussion}

Enterococci are Gram-positive cocci harboring potential probiotic features; however, the emergence of multi-antibiotic resistance and nosocomial infections are major hurdles for assigning GRAS status (HANCHI et al, 2018). In the present study, four different dairy origin E. faecium were characterized and strategy for screening of putative probiotic enterococci was designed. Dahi, fermented buffalo milk product is commonly used in rural and urban regions of Pakistan. In the present study, four different E. faecium strains are isolated and genetically characterized based on sequence analysis of 16S rRNA. All isolates can metabolize different monosaccharides (5C and 6C) and disaccharides. In comparison to previously reported E. faecium, the isolates E. faecium SANA1 and SANA2 can ferment arabinose (MANERO and BLANCH, 1999). The isolates displayed the presence of different metabolic enzymes including $\beta$-galactosidase, arginine dihydrolase, leucine arylamidase, and pyrrolidonyl aminopeptidase. The presence of different metabolic enzymes and fermentation of various monosaccharides and disaccharides make the isolates metabolic diverse bacteria. All enterococci can thrive in acidic conditions of stomach, alkaline environment of the intestine and were non-hemolytic, these findings are comparable to previous reports (MANERO and BLANCH, 1999, BAGCI et al, 2019).

All the screened Enterococci were found sensitive to ampicillin and other commonly administered drugs against Gram-positive bacteria, this is in exact accordance with the desired probiotic characteristics emphasized by EFSA (RYCHEN et al, 2018). All isolates were susceptible to test antibiotics and lacked blaZ, mef A and mefE genes. Although susceptibility to test antibiotics, the enterococci harbored a range of antibiotic resistance genes namely $\operatorname{van} \mathrm{R}, \operatorname{van} \mathrm{X}, q n r \mathrm{~B} 2, q n r \mathrm{~S}, t e t \mathrm{~K}$, and $t e t \mathrm{~W}$. According to the literature survey, there are six different mechanisms responsible for vancomycin resistance in enterococci, the $\operatorname{van} \mathrm{A}(\operatorname{van} \mathrm{X}$ and $\operatorname{van} \mathrm{R}$ genes) and $\operatorname{van} \mathrm{B}$ mediated glycopeptide are clinically important. In contrast to previous studies conducted on vancomycin sensitive/variable enterococci, all isolates were phenotypically sensitive to vancomycin and lack $\operatorname{van} \mathrm{A}$ resistance determinants (SZAKACS et al, 2014). Importantly, in contrast to previous studies, in present work quinolone resistance pentapeptide decoding genes $q n r \mathrm{~A}, q n r \mathrm{~B} 2$, and $q n r \mathrm{~S}$ genes are amplified from the isolates (CHANG et al, 2009). As per EFSA guidelines, The Enterococci strains to be used as probiotics should be susceptible to ampicillin with a MIC $\leq 2 \mu \mathrm{g} / \mathrm{ml}$. However, the full genome sequence is essential for the approval of probiotic candidates by EFSA (HANCHI et al, 2018).

Lactic acid bacteria can decarboxylate amino acids and produce low molecular weight nitrogenous moieties known as biogenic amines (LINARES et al, 2011). Putrescine, histamine, and tyramine are famous biogenic amines with well-known toxicity (DE PALENCIA et al, 2011). Previously, putrescine and tyramine producing E. durans, E. faecium, and E. faecalis were isolated from meat, cheese, animals and human (LADERO et al, 2012). According to our knowledge, it is the first study representing the presence of putrescine producing $E$. faecium in Dahi (buffalo milk yogurt).

Previously extensive work had been conducted on antagonistic activity of various strains of enterococci (E. durans, E. faecium and E. faecalis) against different 
pathogenic bacteria and fungi including Klebsiella pneumoniae, Pseudomonas aeruginosa, Salmonella Paratyphi, Vibrio cholerae, Bacillus cereus, Listeria monocytogenes, Staphylococcus aureus, Staphylococcus epidermidis, Streptococcus pyogenes, Candida albicans and Aspergillus niger (ZHENG et al, 2015, SIMONETTA et al, 1997, ENNAHAR and DESCHAMPS, 2000). The study demonstrated the strong antagonistic activity of enterococci isolates against MDR enteropathogenic E. coli SABA3 and S. Typhi SABA10. E. faecium SANA1 and its CFCS showed strong antibacterial activity against $E$. coli SABA3 and S. Typhi SABA10 in contrast to an earlier report (Table 4) (CASTELLANO et al, 2017).

Table 4. Bacteriogenic activity of dairy origin E. faecium against different Gram-positive and negative pathogens

\begin{tabular}{|c|c|c|c|}
\hline $\begin{array}{l}\text { Country of } \\
\text { Origin }\end{array}$ & Food Name & Targeted Test Pathogens & Reference \\
\hline Argentina & Tafi' cheese & Listeria monocytogenes, Listeria innocua & $\begin{array}{l}\text { (SAAVEDRA } \\
\text { et al, 2003) }\end{array}$ \\
\hline Brazil & Soft cheese & Listeria monocytogenes, Staphylococcus aureus & $\begin{array}{l}\text { (ORTOLANI } \\
\text { et al, 2010) }\end{array}$ \\
\hline Bulgaria & $\begin{array}{l}\text { White brine } \\
\text { cheese }\end{array}$ & $\begin{array}{l}\text { Listeria monocytogenes, Lactobacillus paracasei, Listeria ivanovii, } \\
\text { Listeria innocua, Enterococcus mundtii, Enterococcus faecalis }\end{array}$ & $\begin{array}{l}\text { (FAVARO } \\
\text { et al, 2014) }\end{array}$ \\
\hline Greece & Feta cheese & Listeria monocytogenes & $\begin{array}{l}\text { (NASCIMENTO } \\
\text { et al, 2010) }\end{array}$ \\
\hline Iran & Koopeh cheese & Listeria monocytogenes & $\begin{array}{l}\text { (HASSANZADA } \\
\text { ZAR et al, 2014) }\end{array}$ \\
\hline Mongolia & Tarag (yogurt) & $\begin{array}{l}\text { Listeria monocytogenes, Listeria ivanovii, Listeria innocua, } \\
\text { Lactobacillus bulgaricus, Lactobacillus brevis }\end{array}$ & $\begin{array}{l}\text { (HADJI-SFAXI } \\
\text { et al, 2011) }\end{array}$ \\
\hline Pakistan & Dahi (yogurt) & Escherichia coli, Salmonella enterica & Present study \\
\hline Turkey & White cheese & Listeria ivanovii, Listeria innocua, Enterococcus faecalis & $\begin{array}{l}\text { (TOĞAY } \\
\text { et al, 2016) }\end{array}$ \\
\hline USA & $\begin{array}{l}\text { Queso Fresco and } \\
\text { Mennonite cheeses }\end{array}$ & Listeria monocytogenes, Enterococcus durans & $\begin{array}{l}\text { (RENYE } \\
\text { et al, 2009) }\end{array}$ \\
\hline
\end{tabular}

According to the chemical analysis of CFCS, lactic acid and acetic acid were major organic acids secreted by the isolates. The antagonistic activity of CFCS remained unchanged even after proteinase $\mathrm{K}$ treatments and $\mathrm{pH}$ fluctuations. However, antibacterial activity was lost after heat treatment indicates the presence of thermolabile, $\mathrm{pH}$ and proteinase $\mathrm{K}$ resistant moieties, which are responsible for strong antibacterial activity. Enterococci are generally tolerant to the extreme conditions including $\mathrm{pHs}$, high salt concentration and temperatures. Moreover, enterococci strains were found to harbor many bacteriocin encoding genes that offer a competitive advantage over other bacterial species in various environmental conditions. These features are particularly valuable for their wide applications food industry to avoid the spoilage and the contamination of pathogenic microbes (HANCHI et al, 2018).

Multiple trials have been done to appraise the probiotic potential of enterococci, with the main emphasis on E. faecium. Owing to safety issues, lack of safety data and legislations, only a few strains are commercially available. Enterococci have not yet got a GRAS status (FRANZ et al, 2011). But, strains such as E. faecium SF-68 and E. faecium M74 are in use as probiotics and food supplements with proven safety and efficacy, such as Symbioflor $^{\circledR} 1$ with E. faecalis (Symbiopharm, Herborn,
Germany), FortiFlora ${ }^{\circledR}$ and Cernivet ${ }^{\circledR}$ (containing E. faecium SF68 ${ }^{\circledR}$, Cerbios-Pharma SA, Switzerland) (SERIO et al, 2010). It is important to screen continental and commercially available fermented foods for the detection and characterization of new probiotic enterococci safe for human and animal use.

\section{Conflict of Interest}

The authors have no conflict of interest to declare.

\section{References}

1. AARESTRUP FM, AGERSO Y, GERNER-SMIDT P, MADSEN M, JENSEN LB. Comparison of antimicrobial resistance phenotypes and resistance genes in Enterococcus faecalis and Enterococcus faecium from humans in the community, broilers, and pigs in Denmark. Diagn Microbiol Infect Dis. 2000; 37, 127-37.

2. AZIZ F, KHAN MN, AHMED S, ANDREWS SC. Draft genome sequence of Enterococcus faecium SP15, a potential probiotic strain isolated from spring water. BMC Res Notes. 2019; 12, 99.

3. BAGCI U, TOGAY SO, TEMIZ A, AY M. Probiotic characteristics of bacteriocin-producing Enterococcus faecium strains isolated from human milk and colostrum. Folia Microbiol. 2019, 1-16. 
4. CASTELLANO P, PÉREZ IBARRECHE M, BLANCO MASSANI M, FONTANA C, VIGNOLO G. Strategies for pathogen biocontrol using lactic acid bacteria and their metabolites: a focus on meat ecosystems and industrial environments. Microorganisms. 2017; 5, 38.

5. CHANG L, ZHANG Z-Y, KE D, JIAN-PING Y, XIAO-KUI G. Antibiotic resistance of probiotic strains of lactic acid bacteria isolated from marketed foods and drugs. Biomed Environ Sci. 2009; 22, 401-412.

6. CLSI 2018. M100 Performance Standards for Antimicrobial Susceptibility Testing. CLSI.

7. DE PALENCIA PF, FERNÁNDEZ M, MOHEDANO ML, LADERO V, QUEVEDO C, ALVAREZ MA, LÓPEZ P. Role of tyramine synthesis by food-borne Enterococcus durans in adaptation to the gastrointestinal tract environment. Appl Environ Microbiol. 2011; 77, 699-702.

8. DUBIN K, PAMER EG. Enterococci and their interactions with the intestinal microbiome. Microbiol Spectr. 2014; 5.

9. ENNAHAR S, DESCHAMPS N. Anti-Listeria effect of enterocin A, produced by cheese-isolated Enterococcus faecium EFM01, relative to other bacteriocins from lactic acid bacteria. J Appl Microbiol. 2000; 88, 449-457.

10. FAVARO L, BASAGLIA M, CASELLA S, HUE I, DOUSSET $X$, DE MELO FRANCO BDG, TODOROV SD. Bacteriocinogenic potential and safety evaluation of non-starter Enterococcus faecium strains isolated from home made white brine cheese. Food Microbiol. 2014; 38, 228-239.

11. FRANZ CM, HUCH M, ABRIOUEL H, HOLZAPFEL W, GÁLVEZ A. Enterococci as probiotics and their implications in food safety. Int J Food Microbiol. 2011; 151, 125-140.

12. GUEIMONDE M, SANCHEZ B, C GDLR-G, MARGOLLES A. Antibiotic resistance in probiotic bacteria. Front Microbiol. 2013; 4, 202.

13. HADJI-SFAXI I, EL-GHAISH S, AHMADOVA A, BATDORJ B, LE BLAY-LALIBERTÉ G, BARBIER G, HAERTLÉ T, CHOBERT J-M. Antimicrobial activity and safety of use of Enterococcus faecium PC4. 1 isolated from Mongol yogurt. Food Control. 2011; 22, 2020-2027.

14. HANCHI H, MOTTAWEA W, SEBEI K, HAMMAMI R. The Genus Enterococcus: Between Probiotic Potential and Safety Concerns-An Update. Front Microbiol. 2018; 9, 1791.

15. HASSANZADAZAR H, EHSANI A, MARDANI K. Antibacterial activity of Enterococcus faecium derived from Koopeh cheese against Listeria monocytogenes in probiotic ultra-filtrated cheese. Vet Res Forum. 2014; $5,169-175$.
16. KHAN AA, KHURSHID M, KHAN S, ALSHAMSAN A. Gut Microbiota and Probiotics: Current Status and Their Role in Cancer Therapeutics. Drug Develop Res. 2013; 74, 365-375.

17. KHURSHID M, ASLAM B, NISAR MA, AKBAR R, RAHMAN H, KHAN AA, RASOOL MH. Bacterial munch for infants: potential pediatric therapeutic interventions of probiotics. Future Microbiol. 2015; 10, 1881-1895.

18. LADERO V, FERNÁNDEZ M, CALLES ENRÍQUEZ M, SÁNCHEZ-LLANA E, CAÑEDO E, MARTÍN MC, ALVAREZ MA. Is the production of the biogenic amines tyramine and putrescine a specieslevel trait in enterococci? Food Microbiol. 2012; 30, 132-138.

19. LAULUND S, WIND A, DERKX P, ZULIANI V. Regulatory and safety requirements for food cultures. Microorganisms. 2017; 5, 28.

20. LEE K-Y, SO J-S, HEO T-R. Thin layer chromatographic determination of organic acids for rapid identification of bifidobacteria at genus level. $J$ Microbiol Methods. 2001; 45, 1-6.

21. LINARES DM, MARTÍN M, LADERO V, ALVAREZ MA, FERNÁNDEZ M. Biogenic amines in dairy products. Crit Rev Food Sci Nutr. 2011; 51, 691-703.

22. MAGIORAKOS AP, SRINIVASAN A, CAREY RB, CARMELI Y, FALAGAS ME, GISKE CG, HARBARTH S, HINDLER JF, KAHLMETER G, OLSSON-LILJEQUIST B, PATERSON DL, RICE LB, STELLING J, STRUELENS MJ, VATOPOULOS A, WEBER JT, MONNET DL. Multidrug-resistant, extensively drug-resistant and pandrug-resistant bacteria: an international expert proposal for interim standard definitions for acquired resistance. Clin Microbiol Infect. 2012; 18, 268-81.

23. MANERO A, BLANCH AR. Identification of Enterococcus spp. with a biochemical key. Appl Environ Microbiol. 1999; 65, 4425-4430.

24. MILLER WR, MUNITA JM, ARIAS CA. Mechanisms of antibiotic resistance in enterococci. Expert Rev Anti Infect Ther. 2014; 12, 1221-36.

25. NAMI Y, VASEGHI BAKHSHAYESH R, MOHAMMADZADEH JALALY H, LOTFI $H$, ESLAMI S, HEJAZI MA. Probiotic properties of Enterococcus isolated from artisanal dairy products. Front Microbiol. 2019; 10, 300.

26. NASCIMENTO MDSD, MORENO I, KUAYE AY. Antimicrobial activity of Enterococcus faecium FAIR-E 198 against gram-positive pathogens. Braz J Microbiol. 2010; 41, 74-81.

27. ORTOLANI MBT, YAMAZI AK, MORAES PM, VIÇOSA GN, NERO LA. Microbiological quality and safety of raw milk and soft cheese and detection of 
autochthonous lactic acid bacteria with antagonistic activity against Listeria monocytogenes, Salmonella spp., and Staphylococcus aureus. Foodborne Pathog Dis. 2010; 7, 175-180.

28. RENYE JA, SOMKUTI GA, PAUL M, VAN HEKKEN DL. Characterization of antilisterial bacteriocins produced by Enterococcus faecium and Enterococcus durans isolates from Hispanic-style cheeses. J Ind Microbiol Biotechnol. 2009; 36, 261.

29. RYCHEN G, AQUILINA G, AZIMONTI G, BAMPIDIS V, BASTOS MDL, BORIES G, CHESSON A, COCCONCELLI PS, FLACHOWSKY G, Guidance on the characterisation of microorganisms used as feed additives or as production organisms. EFSA J. 2018; 16, e05206.

30. SAAVEDRA L, TARANTO MP, SESMA F, DE VALDEZ GF, Homemade traditional cheeses for the isolation of probiotic Enterococcus faecium strains. Int J Food Microbiol. 2003; 88, 241-245.

31. SERIO A, CHAVES-LÓPEZ C, PAPARELLA A, SUZZI G, Evaluation of metabolic activities of enterococci isolated from Pecorino Abruzzese cheese. Int Dairy J. 2010; 20, 459-464.

32. SHAHID M, HUSSAIN B, RIAZ D, KHURSHID M, ISMAIL M, TARIQ M, Identification and partial characterization of potential probiotic lactic acid bacteria in freshwater Labeo rohita and Cirrhinus mrigala. Aquac Res. 2017; 48, 1688-1698.

33. SIMONETTA A, MORAGUES DE VELASCO L, FRISON L, Antibacterial activity of enterococci strains against Vibrio cholerae. Lett Appl Microbiol. 1997; 24, 139-143.

34. SZAKACS TA, KALAN L, MCCONNELL MJ, ESHAGHI A, SHAHINAS D, MCGEER A, WRIGHT GD, LOW DE, PATEL SN, Outbreak of vancomycinsusceptible Enterococcus faecium containing the wildtype vanA gene. J Clin Microbiol. 2014; 52, 1682-1686.

35. TODOROV SD, DICKS LM, Characterization of mesentericin ST99, a bacteriocin produced by Leuconostoc mesenteroides subsp. dextranicum ST99 isolated from boza. Ind Microbiol Biotechnol. 2004; 31, 323-329.
36. TOĞAY SÖ, AY M, GÜNEŞER O, YÜCEER YK, Investigation of antimicrobial activity and entA and entB genes in Enterococcus faecium and Enterococcus faecalis strains isolated from naturally fermented Turkish white cheeses. Food Sci Biotechnol. 2016; 25, 1633-1637.

37. TOĞAY SÖ, KESKIN AÇ, AÇ1K L, TEMIZ A, Virulence genes, antibiotic resistance and plasmid profiles of Enterococcus faecalis and Enterococcus faecium from naturally fermented Turkish foods. Lett Appl Microbiol. 2010; 109, 1084-1092.

38. TURPIN W, HUMBLOT C, GUYOT J-P, Genetic screening of functional properties of lactic acid bacteria in a fermented pearl millet slurry and in the metagenome of fermented starchy foods. Appl Environ Microbiol. 2011; 77, 8722-8734.

39. WEINER LM, WEBB AK, LIMBAGO B, DUDECK MA, PATEL J, KALLEN AJ, EDWARDS JR, SIEVERT DM, Antimicrobial-Resistant Pathogens Associated With Healthcare-Associated Infections: Summary of Data Reported to the National Healthcare Safety Network at the Centers for Disease Control and Prevention, 2011-2014. Infect Control Hosp Epidemiol. 2016; 37, 1288-1301.

40. ZHAO W, LIU Y, LATTA M, MA W, WU Z, CHEN P, Probiotics database: a potential source of fermented foods. Int J Food Prop. 2019; 22, 197-216.

41. ZHENG W, ZHANG Y, LU H-M, LI D-T, ZHANG Z-L, TANG Z-X, SHI L-E, Antimicrobial activity and safety evaluation of Enterococcus faecium KQ 2.6 isolated from peacock feces. BMC Biotechnol. 2015; 15,30 .

42. ZOMMITI M, CAMBRONEL M, MAILLOT O, BARREAU $M$, SEBEI $K$, FEUILLOLEY M, FERCHICHI M, CONNIL N, Evaluation of Probiotic Properties and Safety of Enterococcus faecium Isolated From Artisanal Tunisian Meat "Dried Ossban”. Front Microbiol. 2018; 9, 1685. 